\title{
ANTIMICROBIAL EFFICACY OF BARK EXTRACTS OF “RANDIA ULIGINOSA" ON ORAL PATHOGENS: RESEARCH STUDY.
}

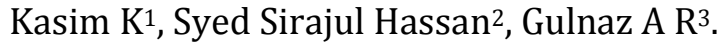

1. Professor, Department of Oral \& Maxillofacial Pathology, Farooqia Dental College \& Hospital, Mysore-21.

2. Assistant Professor, Department of Oral \& Maxillofacial Surgery, Farooqia Dental College \& Hospital, Mysore-21.

3. Assistant Professor, Department of Biochemistry, Farooqia Dental College \& Hospital, Mysore-21.

\section{CORRESPONDING AUTHOR}

Dr Syed Sirajul Hassan,

Assistant Professor,

Department of Oral \& Maxillofacial Surgery,

Farooqia Dental College, Umar Khayyam Road,

Tilaknagar, Mysore - 21.

Email-siraj827@hotmail.com

\section{HOW TO CITE THIS ARTICLE:}

Kasim K, Syed Sirajul Hassan, Gulnaz A R. "Antimicrobial Efficacy of bark Extracts of "Randia Uliginosa” on Oral Pathogens: Research study". Journal of Evolution of Medical and Dental Sciences 2013; Vol2, Issue 24, June 17; Page: 4260-4263.

ABSTRACT: India has rich plant diversity. The people in India are using these plants for medicinal purposes. This practice is common in other developing countries also. The drugs obtained from Different of plants are used in various traditional as well as modern Practices.The present investigation is aimed at investigating the in vitro Successive solvent extract viz., petroleum ether, chloroform, methanol, and water extracts of stem bark of Randia uliginosa. was evaluated for antibacterial activity, against four important bacterial strains S. aureus Escherichia coli, Lacto bacillus, and Enterococcus fecalis by agar-well diffusion method. All the solvent extract showed significant activity against all the tested bacteria, The antibacterial activity is more significant in solvent extracts compared to aqueous extract indicating that the active principle responsible for antibacterial activity is more soluble in organic solvents Comparison of the inhibitory activity of the extracts with the antibiotics Gentamicin revealed that methanol extracts of Randia uliginosa was significantly higher than that of the antibiotics tested. The results suggest that Randia uliginosa. Can be used as a medicament for oral infection

KEY WORDS: Randia uliginosa. Antibacterial activity, oral pathogens Methanol extract

INTRODUCTION: Herbal medicine is the oldest form of health care known to mankind. In terms of using plant materials for traditional medicine, it is estimated that local communities use over 7,500 species of plants (Anonymous 1994; Arora 1997). Medicinal plants, which form the backbone of traditional medicine, have in the last few decades been the subject for very intense pharmacological studies; this has been brought about by the acknowledgement of the value of medicinal plants as potential sources of new compounds of therapeutics value and as sources of lead compounds in the drug development. In developing countries, it is estimated that about $80 \%$ of the population rely on 


\section{ORIGINAL ARTICLE}

traditional medicine for their primary health care directly or indirectly. Hence it is very much essential to screen medicinal plants for bioactive compounds which are the basis for further pharmacological studies. In recent years, multiple drug resistance in human have been developed due to indiscriminate use of commercial antimicrobial drugs commonly used in the treatment of infectious diseases. This situation has forced scientists to search new antimicrobial substances in various sources like medicinal plants (Kumar et al., 2006). Medicinal and aromatic plants and their essences are rich in antibacterial compounds which could be an alternate way to combat bacterial diseases even against some bacteria which are becoming resistant to certain synthetic medicines (Meera et al., 1999; Ahmad et al., 1998; Aswal et al., 1996).Plant derived drugs have been used for various ailments due to less side effects and potential efficacy. Plants have potent ability to synthesize aromatic substances, most of which include alkaloids, Quinones, Flavones, Tannins, phenols or their oxygen-substituted derivatives [1]. In many cases, these substances serve as plant defence mechanisms against predation by microorganisms, insects and herbivores.

The selected plant Randia uliginosa belongs to the family Rubiacea. The plant grows in dry deciduous forests, native to Bangladesh, India, Sri Lanka, and Thailand. In Kerala, it is usually grows in the moist deciduous forest ranging from Wayanad to Thiruvananthapuram,it is locally used as a medicine. The different parts of the plant are used for various ailments like Cholera, diarrhoea, dysentery, eye complaints, pimples, diuretic, tonic properties, biliousness, aphrodisiac, the stem bark ground with white layer of country egg, turmeric and calcium and bandaged on wounds and bone fractures [2] Other than these pharmacological uses, the koyaguda local people named this plant as kumudmara and they used raw fruits as vegetables. The fruits are eaten boiled or roasted, either alone or in curries. The unripe fruit is astringent. It is used in dyeing as a colour intensifier. The leaves are boiled and eaten. They are used as fodder for deer and cattle. Flowers yield an essential oil similar to Gardenia oil.

Oral hygiene is an integral part of health of a person. Oral health when neglected, results in different Oral disorders which can be significantly affecting the general well-being of a person by causing considerable pain and discomfort thus affecting their quality of life, however it has been given least importance among the rural population. Most of the medications used in the treatment are in the form of antibiotics and analgesics which are chemical in nature \& has lots of side effects, so the present investigation was undertaken to evaluate the antibacterial activity of stem bark extracts of the plant Randia uliginosa on some selected oral pathogens.

\section{MATERIALS AND METHODS:}

2.1 COLLECTION OF PLANT MATERIAL: The plant material of Randia uliginosa was collected from Wayanad District, Kerala. The plant was taxonomically identified from the taxonomist.

2.2 PREPARATION OF PLANT EXTRACTS: The fresh bark was dried under shade. The dried plant material were powdered and ground plant material was extracted sequentially with petroleum ether, chloroform Ethyl Acetate methanol and water in their increasing order of polarity by Soxhlet method for 18 hours with each solvent[3,4]. The crude extract were filtered through Whatman filter paper and concentrated at $40^{\circ} \mathrm{C}$ under vacuum using a rotary evaporator. The concentrated extracts were dried at room temperature and stored in air tight glass vials and stored at $4^{\circ} \mathrm{c}$ until further use. 


\section{ORIGINAL ARTICLE}

2.3 TEST ORGANISMS: Oral pathogenic organisms were isolated from clinical samples are used in this study, the microorganisms were collected from department of oral pathology and microbiology, Farooqia dental college \& Hospital Mysore, four oral pathogens used are S. aureus Escherichia coli, Lacto bacillus, and Enterococus fecalis.

2.4 ANTIMICROBIAL ACTIVITY BY DISC DIFFUSION METHOD: The disc diffusion assay methods of Iennette (1985) as described by Rosoanaivo and Ratsimanaga- Urverg (1993) and Rabe and Van Staden (1997), with modifications, were used to determine the growth inhibition of bacteria by plant extracts. The inoculums of microorganisms was Adjusted to 0.5 McFarland standard, diluted bacterial culture $(100 \mu \mathrm{l})$ was spread over nutrient agar plates with a sterile swab. $100 \mu \mathrm{l}$ of the each extracts were applied to each filter paper disc (Whatman No. 1, $6 \mathrm{~mm}$ diam.) and allowed to dry before being placed on the agar plate [5]. Each extract was tested in triplicate and the plates were inoculated at $37^{\circ} \mathrm{C}$ for $24 \mathrm{~h}$. Antimicrobial activities were evaluated by measuring inhibition zone diameters. Gentamicin was used as positive control.

STATISTICAL ANALYSIS: All the experiments were seeded in triplicate and data thus obtained was reported as mean \pm standard deviation (SD).

RESULTS AND DISCUSSION: Plants are important source of potentially useful sources for the development of new chemotherapeutic agents. The first step towards this goal is the in vitro antibacterial activity assay (Tona, et al., 1998). Table: 1 reveals the antibacterial activity of different solvent extracts and also aqueous extract.

A maximum zone of inhibition was observed against all the four test oral pathogens S. aureus Escherichia coli, Lacto bacillus, and Enterococus fecalis by methanol extracts of stem bark of the plant Randia uliginosa, followed by Ethyl acetate and chloroform extracts, petroleum ether, extract showed less zone of inhibition in comparison with the other extracts. Aqueous extract did not show significant activity against the entire four test organism.

Antibiotics provide the main basis for the therapy of bacterial infections. However, the high genetic variability of bacteria enables them to rapidly evade the action of antibiotics by developing antibiotic resistance. In recent years development of multidrug resistance in the pathogenic bacteria and parasites has created major clinical problems in the treatment of infectious diseases [6]. And the other problems such as toxicity of certain antimicrobial drugs on the host tissue $[7,8]$ triggered interest in search of new antimicrobial substances/drugs of plant origin. Considering the rich diversity of plants [9], it is expected that screening and scientific evaluation of plant extracts for their anti-bacterial activity may provide new antibacterial substances, hence the present investigation clearly reveals the antibacterial nature of this plant and suggests that this plant could be exploited in the management of oral diseases caused in man.

It is interesting to note that antibacterial activity was highly pronounced in solvent extract compared to Aqueous extract. It is also important to note that susceptibility of the pathogens was varied to solvents. The present finding is highly encouraging in recognizing the plant Randia uliginosa as an anti bacterial against oral pathogens In addition, this result forms a good basis for selection of the plant for further phytochemical and pharmacological investigation and suggests 
antibacterial properties that can be used as antimicrobial agents, new drugs for the therapy of infectious diseases caused by oral pathogens.

In vitro antibacterial activity of stem bark extracts of the plant Randia uliginosa on some selected oral pathogens.

\begin{tabular}{|l|l|l|l|l|l|l|l|l|}
\hline \multirow{2}{*}{$\begin{array}{l}\text { Sl. } \\
\text { No }\end{array}$} & \multirow{2}{*}{$\begin{array}{l}\text { Oral } \\
\text { pathogens }\end{array}$} & $\begin{array}{l}\text { Petroleum } \\
\text { ether }\end{array}$ & Chloroform & $\begin{array}{l}\text { Ethyl } \\
\text { acetate }\end{array}$ & Methanol & Water & Gentamicin & DMSO \\
\hline 1 & S. aureus & 10 & 13 & 16 & 18 & 09 & 15 & - \\
\hline 2 & E. coli & 09 & 15 & 17 & 18 & 11 & 16 & - \\
\hline 3 & E. fecalis & 10 & 14 & 15 & 19 & 10 & 13 & - \\
\hline 4 & Lactobacillus & 11 & 14 & 16 & 20 & 10 & 16 & - \\
\hline
\end{tabular}

Values are mean inhibition zone $(\mathrm{mm}) \pm$ S.D of three replicates

\section{REFERENCES:}

1. Nandagopal, S. and B.D. Ranjitha Kumari, 2007.Phytochemical and antibacterial studies of Chicory (Cichorium intybus L.)- A multipurpose medicinal plant. Advan. Biol. Res., 1(1-2): 1721.

2. K. Venkata Ratnam and R.R. Venkata Traditional Medicine Used by the Adivasis of Eastern Ghats, Andhra Pradesh - For Bone Fractures

3. Kokate, C.K., 1999. Practical Pharmacognosy. Vallabh and Prakashan, New Delhi. pp: 149156.

4. Vardar-nluG, CandanF., Sokemen DaferraD, Pollissiou M, Sokemen M, Antimicrobial and antioxidant activity of then essential Oil and methanol extract of Thymus pectinatus

5. Journal of agricultural and food chemistry. 2003; 61-67

6. National Committee for Clinical Laboratory Standards (NCCLS). Performance standard for antimicrobial disk susceptibility test. Approved standard NCCLS document M2-A7. Wayne Pa 2000.

7. Davies, J., 1994. Inactivation of antibiotics and the dissemination of resistance genes. Sci., 264: 375-382

8. Idose, O, T Guthe, R. Willeox and A.L. Deweck. 1968. Nature and extent of penicillin side reaction with particular reference to fatalities from anaphylactic shock. Bulletin of WHO 38: 159-188

9. Maddux, M.S. and S.L. Barrere, 1980. A review of complications of amphotericin-B therapy: recommendations for prevention and management. Drug Intelligence and Clinical Pharmacy. 14: 177-181.

10. Cowan, M.M., 1999. Plant Products as Antimicrobial Agents, Clinical Microbiology Reviews, Oct 12 (4): 564-582. 